\title{
Dialektika Regulasi Pertambangan Pemerintah Indonesia dan PT Freeport Indonesia melalui Pendekatan Obsolescing Bargaining Model
}

\author{
Angga Danu Fadil Irawan \\ Sarjana Ilmu Hubungan Internasional Universitas Pasundan \\ email: adfadilirawan@gmail.com
}

| submit: 16-07-2020 | accept:26-01-2021 | publish: 31-01-2021

\author{
Keywords \\ Mineral and Coal Mining; \\ Neomercantilism; \\ Obsolescing Bargaining \\ Model; PT. Freeport \\ Indonesia.
}

\begin{abstract}
Implementation of Law no. 4 of 2009 concerning Mineral and Coal Mining in Indonesia was the beginning of a polemic of renegotiating policies and conflicting political-economic interests between the Government of Indonesia (Host State) and PT Freeport Indonesia (Multi-National Corporation). This article will analyze the process of renegotiating the Special Mining Business Permit (IUPK) as stated in Law no. 4 of 2009 through a bargaining power scenario between the two conflicting actors. The analysis will carry through a qualitative approach with descriptive analysis methods and literature studies. The author will focus on the interpretation within the spectrum of the neomercantilism paradigm to investigate variables that are more oriented to the interests of the state (state-centric model of bargaining). By means of this approach, the Government of Indonesia and PT Freeport Indonesia will have articulated through the Obsolescing Bargaining model. The outcomes of the analysis assert the dominance of the Indonesian Government as a Host-State in the IUPK renegotiation process.
\end{abstract}

\begin{abstract}
ABSTRAK
Implementasi UU No. 4 Tahun 2009 tentang Pertambangan Mineral dan Batubara di Indonesia menjadi awal dari polemik renegosiasi kebijakan dan kepentingan ekonomi politik yang berlawanan di antara Pemerintah Indonesia (Host State) dan PT Freeport Indonesia (Multi National Corporation). Artikel ini akan menganalisis bagaimana proses renegosiasi Izin Usaha Pertambangan Khusus (IUPK) yang tertera di dalam UU No. 4 Tahun 2009 melalui skenario daya tawar (bargaining power) di antara kedua aktor yang bertikai. Analisis dilakukan melalui pendekatan kua litatif dengan metode analisis deskrip tif yang bersumber pada studi kepustakaan. Penulis akan menitikberatkan analisis melalui spektrum paradigma neomerkantilisme untuk melakukan eksplorasi variabel yang lebih berorientasi pada kepentingan negara (state centric model of bargaining). Melalui pendekatan tersebut, Pemerintah Indonesia dan PT Freeport Indonesia akan diartikulasikan posisi tawarnya melalui Obsolescing Bargaining Model. Hasil analisis mengacu pada posisi dominan Pemerintah Indonesia dalam proses renegosiasi IUPK sehingga hasil artikulasi daya tawar akan lebih berorientasi pada keuntungan Pemerintah Indonesia sebagai HostState.
\end{abstract}




\section{PENDAHULUAN}

Proses integrasi ekonomi global beserta kebijakan politik suatu negara telah menciptakan relasi saling ketergantungan (mutual interdependency) di antara para pelaku perdagangan internasional (Leiteritz, 2004). Kembalinya rezim perdagangan yang berpusat pada negara sebagai aktor dominan, telah berhasil menggeser agenda keuntungan relatif yang ditawarkan oleh sistem pasar neoliberal (Mastanduno, 1991: 73) Pasca kolapsnya pasar akibat krisis energi pada tahun 1970, negara lebih memilih untuk mengoperasionalkan kedaulatannya dalam melindungi stabilitas ekonomi domestiknya (Gilpin, 2016: 360). Kecenderungan tersebut dapat dilihat dari kebangkitan ekonomi nasionalis yang kembali pesimis terhadap mekanisme pasar neoliberal global. Hal tersebut dikuatkan dengan tendensi negara berkembang untuk menerapkan sistem nilai tukar tetap (fix exchange rate) yang muncul sebagai tren internasional pada tahun 1990-an (Gilpin, 2016: 386).

Pascakrisis 2008, Indonesia menjadi negara yang produktif dalam menghasilkan kebijakan proteksionis yang membatasi aktivitas ekspor dan impor. Berdasarkan laporan GTA (Global Trade Alert) Indonesia masuk ke dalam negara dengan status "offender" akibat eskalasi produk-produk regulasi yang protektif sejak tahun 2009-2015 (Evenett, 2014). Setkebijakan seperti hambatan nontarif (Non-Tariff Measurement-Barrier) dan pajak ekspor digelontorkan Pemerintah Indonesia akibat dari depresiasi finansial dan ketidakpastian pergerakan nilai tukar pascakrisis finansial 2008.

Salah satu geliat kebijakan Indonesia yang saat itu mencuat, dapat dilihat pada regulasi industri pertambangan mineral dan batubara melalui penetapan Undang-Undang No. 4 Tahun 2009 tentang Mineral dan Batubara. Penetapan undang-undang tersebut ditujukan sebagai pengganti materi muatan dalam Undang-Undang No. 11 tahun 1967 tentang Ketentuan-Ketentuan Pokok Pertambangan yang dipandang bersifat market-oriented dan tidak sesuai dengan situasi ekonomi-politik domestik Indonesia saat ini.

Di samping itu, pembangunan industri pertambangan harus mampu beradaptasi dengan perubahan lingkungan strategis baik dalam ruang lingkup nasional maupun internasional (UU No. 4 Tahun 2009, TLN No. 4959). Konteks ini, melatarbelakangi adanya penyesuaian-penyesuaian regulatif dan operasional dalam industri pertambangan. Perubahan mendasar yang paling mencolok dari UU No. 4 Tahun 2009 tersebut, terkait penggolongan bahan galian, sistem pengelolaan dan transformasi sistem rezim dari kontrak menjadi izin (Izin Usaha Pertambangan). Hal ini berdampak signifikan terhadap tata laksana industri pertambangan dari status Kontrak Karya menjadi izin usaha. Sehingga, Pemerintah Indonesia harus melakukan renegosiasi terhadap perusahaan terkait, disebabkan karena paket regulasi tersebut baru diberlakukan sejak 12 Januari 2014.

Pemberlakuan UU No. 4 Tahun 2009 berdampak pada proses hilirisasi industri tambang yang mengalami hambatan operasional. Terutama, PT. Freeport Indonesia (PTFI) yang keberatan atas renegosiasi KK (Kontrak Karya) dikarenakan harus melakukan penyusutan luas wilayah sekitar $75 \%$ dari total wilayah menjadi sekitar 212.290 Ha. Kemudian, proses penyusutan akan dilakukan secara berangsur-angsur dengan kurang lebih $60 \%$ luas wilayah PT Freeport akan dikembalikan kepada negara (ESDM, 2004).

Selain itu, kewajiban divestasi saham sebesar 30\% kepada Pemerintah Indonesia harus diselesaikan pada 2019. Walaupun di dalam Kontrak Karya tahun 1991 sudah ada kewajiban divestasi saham sebesar $51 \%$ kepada Pemerintah Indonesia dalam jangka waktu 20 tahun, kenyataannya, PTFI belum melaksanakan prosedur kesepakatan tersebut dengan justifikasi bahwa Peraturan Pemerintah No. 20 tahun 1994 memperbolehkan perusahaan asing menguasai $100 \%$ saham perusahaan tambang. Walapun kenyataannya, ketentuan tersebut jelas bertentangan dengan 
Kontrak Karya yang mengharuskan divestasi hingga $51 \%$.

Proses peralihan regulasi tersebut telah membawa Indonesia dan PTFI ke dalam proses dialektika posisi tawar dalam menentukan regulasi yang saling menguntungkan atau merugikan. Oleh karena itu, dalam menelaah dinamika tawar menawar di antara negara dan korporasi multinasional (MNCs) sebagai entitas analisis yang rasional dalam ekonomi politik global.

\section{KERANGKA KONSEPTUAL}

\section{Neomerkanitilisme}

Neomerkantilisme merupakan format ekonomi politik yang berupaya memusatkan aktivitas pasar ke dalam kepentingan nasional suatu negara dalam bentuk industrialisasi domestik (Warnecke, 1979). Neomerkantilisme menjadi sebuah paradigma perdagangan intervensionis dengan memanfaatkan pembatasan tarif, pajak dan pembatasan investasi (Hettne, 1993).

Di bawah sistem rezim free-market capitalism, sulit untuk mengidentifikasi suatu pola ekonomi-politik negara ke dalam paradigma yang tunggal alih-alih melihatnya dalam spektrum kebijakan strategis (Gilpin, 2016: 126). Indonesia sebagai negara industri baru (New Development Countries), tentu tidak menganut neomerkantilisme sebagai format kebijakan ekonomi-politiknya. Namun dalam konteks artikel ini, paradigma neomerkantilisme digunakan untuk melacak pola-pola regulasi perdagangan yang protektif. Ini termasuk agenda-agenda 'nasionalisasi' dan domestikasi industri mineral dan batubara di Indonesia yang diasosiasikan ke dalam spektrum neomerkantilisme. Hal ini mengasumsikan bahwa pengoperasionalan perangkat kedaulatan negara; seperti non-Tariff Measure-Barrier dan pembatasan ekspor digunakan untuk meminimalisir liberalisasi industri yang dapat mengancam persaingan industri dalam negeri (Warnecke, 1979).

Di Indonesia sendiri, pengaplikasian neomerkantilisme tidak secara formal tercantum dalam setiap regulasi perdagangan.
Namun, praktik neomerkantilisme dapat ditinjau dari produk kebijakan industri tertentu secara lebih mikro. Seperti dalam industri pertambangan, agrikultur, pangan hingga perikanan yang menerapkan proteksionisme secara normatif. Sejak tahun 2015, telah terjadi peningkatan sekitar $14 \%$ kebijakan regulasi hambatan tarif (Non-Tariff Measurement) yang tersebar di 13 kementrian di Indonesia (Marks, 2020). Format NTM tersebut diupayakan untuk meminimalisir kegagalan pasar, melindungi nilai kompetitif di pasardomestik dan tidak ikut terenyak dalam laba jangka pendek yang ditawarkan oleh doktrin free-market capitalism.

Penulis mengasumsikan format kebijakan protektif di Indonesia dapat dikategorikan sebagai quasi-neomerkantilisme. Yaitu, melakukan reorientasi variabel-variabel kebijakan yang terlalu berorientasi pasar. Dengan melakukan reorientasi seperti yang dilakukan pada sektor pertambangan melalui Undang-Undang No. 4 Tahun 2009 tentang Mineral dan Batubara, Indonesia dapat mengoptimalkan keuntungan, meningkatkan hilirisasi produk di pasar domestik, dan melindungi perusahaan milik negeri untuk mampu bersaing di pasar global. Dengan begitu, Indonesia dapat menjadi aktor dominan dan mampu mempromosikan kepentingan nasionalnya dalam proses liberalisasi industri pertambangan yang dapat mengancam kepentingan nasionalnya.

\section{Obsolescing Bargaining Model}

Di dalam literatur yang ditulis oleh Stopford dan Strange, interaksi tawar menawar dalam menentukan dominasi antarnegara (atau disebut Host-State di dalam paradigma bisnis internasional) memiliki kecenderungan untuk menaikkan posisi tawar sebuah Host-State tanpa mengesampingkan kepentingan bersama di leveldomestik (Stopford et al., 1991). Grosse menegaskan pola aktivitas MNC bermuara pada koordinasi tawar menawar (bargaining) negara yang lebih dominan (atau belum tentu dominan) sesuai dengan domain kesempatan yang ditawarkan (Grosse, 2005: 251). Studi 
tradisional mengenai tawar menawar dan negosiasi dominan di antara dua aktor tersebut dinamakan sebagai Obsolescing Bargain Model (OBM).

Bennet dan Sharpe mengindikasikan keseimbangan daya tawar di antara negara dan MNC tidak dapat mencapai titik kesepakatan (equilibria) apabila tetap mengikuti perkembangan rezim moneter dan arus kapital (Bennett \& Sharpe, 1979, hal. 57). Keluarnya negara dari norma perdagangan free market capitalism akan menyebabkan kerentanan prof it MNC. Indikator-indikator yang menjadi kerentanan mencakup: (1) pengambilalihan perusahaan, (2) perubahaan regulasi yang merugikan, (3) renegosiasi kontrak kerja \& (4) persyaratan operasional kerja (Grosse, 2005).

Merujuk pada model Behrman-Grosse, ada tiga dimensi yang menjadi indikator relasi antara pemerintah negara dan bisnis domestik yang dijalankan, yaitu mengacu pada relative resource, relative stakes dan similarity of interest. Model Behrman-Grosse menghimpun adanya posibilitas terhadap daya tawar yang seimbang di dalam skenario negosiasi. Skema triangular Behrman-Grosse tidak lepas dari konsep triangular diplomacy. Walaupun model OBM menjadi perangkat yang proporsional dalam menganalisakompetisi dan kerja sama di antara negara dan MNC, konsep triangular tersebut melebihi jangkauan OBM dalam memproyeksikan daya tawar di antara negaranegara, negara-firma (MNC) dan firma-firma (Grosse, 2005).

Unit analisis dari konsep tersebut memiliki persamaan walaupun titik beratnya ada pada MNC sebagai unit analisanya. Skenario tersebut dianggap terlalu MNC-sentris. Kritik terhadap model dan skenario tersebut, juga berada pada wilayah kekuatan struktural (structural power) yang dimiliki oleh MNC dan mengesampingkan kapabilitas negara sebagai capital goal-directed.

\section{State Centric Model of Bargaining}

Matthews menjelaskan bahwa upaya untuk mendorong kapasitas negara di dalam bargaining entry berada pada atribut institusi pemerintahan negara itu sendiri (Matthews, 2012: 281). Matthews menganggap bahwa negara didefinisikan sebagai ' a goal-directed' untuk mencapai tujuan kolektif aktor di dalam kedaulatannya.Pierre danPeters sepakat bahwa negara akan tetap menjadi agen kepentingan utama di dalam civil society yang merupakan suatu ekspresi dominan dari tujuan dan kepentingan bersama.

Tiga variabel yang menentukan model daya tawar yang lebih state-centric ditentukan melalui kapasitas negara, kapasitas admininstratif dan kapasitas institusional (Pierre et al., 2001: 209).

Dinamika hubungan daya tawar (bargaining power relationship) yang relatif di antara negara dan MNC memiliki posibilitas kerja sama yang tinggi. Posibilitas persamaan kepentingan yang tinggi tersebut akan menghasilkan regulasi yang longgar dengan kebijakan insentif yang dominan (Grosse, 2005). Oleh karena itu, kondisi daya tawar di antara kedua aktor dominan kecil kemungkinannya untu menemukan pertentangan dan selalu berakhir dengan kesepakatan kerja sama.

Berdasarkan konsep OBM yang digunakan, MNC menjadi suatu subjek utuh di antara relasi tawar menawar dan berorientasi pada hasil. Sebaliknya, MNC sendiri tidak bisa menampik proses politik di antara institusi pemerintahan dan harus melakukan negosiasi dalam dimensi politik domestik berupa tekanan kelompok kepentingan. Menurut Ramamurti, proses ini merupakan tawar menawar two-tier multi-party (Ramamurti, 2012).

Kane mengasosiasikan konsep ini sebagai 'dialektika regulasi' sebagai upaya untuk melacak proses dinamis dari konflik dan resolusi antara kekuatan politik dan ekonomi yang berlawanan (BUSER et al., 1981: 355). Kane menekankan bahwa: “... introducing political power into economic affairs initiates a dialectical process of adjustments and counter adjustments."

Berdasarkan pernyataan tersebut, konflik dialektis akan selesai dengan sendirinya di dalam proses dialektis yang dialami kedua aktor yang bekerjasama. Di samping itu, proses 
dialektika tersebut akan melalui fase mobilisasi, konflik dan resolusi yang melibatkan para aktor yang berinteraksi di beberapa level negosiasi terutama pada level mesosystem. Proses dialektika ini akan menghasilkan keputusan berbentuk investasi baru atau perpanjangan kontrak yang kemudian akan mengalokasikan posisi kedaulatan negara pada hasil negosiasi yang relevan dengan kapasitas perangkat negara yang telah disepakati. Dengan justifikasi tersebut, penulis akan menggunakan pendekatan state centric melalui model obsolescing bargaining Behrman-Grosse.

\section{METODE RISET}

Artikel berikut ini akan menggunakan pendekatan kualitatif dengan metode deskriptif analisis. Melalui pendekatan kualitatif, penulis dapat melakukan telaah fenomenologi terhadap objek penelitian secara holistik dan komprehensif (Neuman, 2014: 14).

Bodgan dan Biklen menyebutkan beberapa fitur yang melandasi pendekatan kualitatif dalam penelitian, yaitu: pendekatan dirumuskan melalui seting alamiah dimana peneliti menjadi instrumen utamanya; data yang dikumpulkan bersifat deskriptif; penelitian dititikberatkan pada akumulasi proses, mengutamakan pengolahan data secara umum dan pemaknaan data menjadi unit analisis yang esensial (Bogdan \& Biklen, 2003: 29). Pendekatan kualitatif berfungsi sebagai instrumen eksplorasi untuk berusaha menganalisis jawaban dari pertanyaan 'mengapa' dan 'bagaimana' secara empirik (Zohrabi, 2013: 254).

Teknik pengumpulan data dilakukan dengan studi kepustakaan dengan sumber berupa dokumen yang mencakup jurnal, buku, naskah kebijakan, artikel dan dokumen penunjang lainnya. Studi kepustakaan dilakukan untuk mengkonfirmasi konsep dan keabsahan teori yang digunakan di dalam proses analisis berikut ini (Neuman, 2014: 219).

Adapun pembatasan masalah dalam artikel berikut ini yang mencakup:
1. Ketetapan Pemerintah Indonesia dalam penerapan regulasi pertambangan terhadap PT Freeport Indonesia melalui UndangUndang No. 4 Tahun 2009 tentang Mineral dan Batubara.

2. Studi kasus melingkupi dua unit analisis, yaitu Pemerintah Indonesia (state) dan PT Freeport Indonesia (MNC).

3. Analisis berada pada posisi tawar Pemerintah Indonesia dan PT Freeport Indonesia melalui melalui Obsolescing Bargaining Model. Model OBM berikut ini akan menelaah daya tawar kedua aktor di dalam skenario dialektika regulasi yang terjadi.

\section{HASIL DAN PEMBAHASAN}

Determinasi Kebijakan Pertambangan oleh Pemerintah Indonesia terhadap PT Freeport Indonesia

Ketetapan UU No. 4 Tahun 2009 didasarkan pada UU No. 1 Tahun 1967 tentang Penanaman Modal Asing sejalan dengan UU No 11 Tahun 1967 tentang Pertambangan Mineral dan Batubara. Secara fundamental, pengaturan yang terdapat dalam substansi UU No 11 Tahun 1967 berisi Ketentuan-Ketentuan Pokok Pertambangan yaitu mengenai perubahan pengusahaan dari Kuasa Pertambangan dan Kontrak Karya/Perjanjian Karya Pengusahaan Pertambangan Batubara (KK/PKPPB). Terjadinya perubahan secara substantif dari KK/PKPPB menjadi izin usaha baik izin usaha pertambangan (IUP), izin usaha pertambangan khusus (IUPK) dan izin pertambangan rakyat (IPR).

Menurut Enrique M. Ortega, bentuk perizinan di sektor pertambangan mineral dan batubara menjadi instrumen kontrol melalui institusi negara. Instrumen tersebut mencakup: (1) menerima, memproses dan mengatur ekplorasi, eksploitasi aplikasi dan hibah lisensi dalam urutan kronologis untuk kegiatan industri, skala besar dan skala kecil; (2) memproduksi dan membuat peta kadaster diperbarui yang tersedia untuk umum di mana hak-hak mineral yang ada, aplikasi yang 
tertunda, dan area yang dibatasi untuk kegiatan pertambangan diarahkan dengan benar; (3) memastikan perizinan yang tumpang tindih, memeriksa kelayakan dan membuat keputusan aplikasi hibah; (4) memastikan kepatuhan pembayaran permintaan teknis; (5) mengumpulkan biaya admininstratif (Sulistyorini \& Zulaekhah, 2018).

Perubahan paradigma usaha dari rezim KK menjadi IUP didasarkan pada pertimbangan berikut ini:

- Walaupun ditinjau melalui neraca perdagangan Indonesia mengalami surplus, namun terjadi diskriminasi terhadap perusahaan swasta domestik yang tidak dapat melakukan pengajuan KK.

- Terjadinya kelonggaran sistematik dalam pemrosesan pertambangan di dalam $\mathrm{KK}^{1}$ yang tidak didasarkan pada proses pertambangan, melainkan bersifat eksploitatif.

- Menghindari ketidakpastian dan keraguraguan pengusaha tentang existing contract.

- Pengusahaan pertambangan melalui izin usaha, memiliki beberapa keunggulan yaitu: hubungan hukumnya: (1) izin bersifat publik, perjanjian bersifat perdata penerapan hukumnya: (2) izin oleh pemerintah, perjanjian oleh perjanjian para pihak; (3) pilihan hukum: izin tidak berlaku pilihan hukum, perjanjian berlaku pilihan hukum; (4) akibat hukum: izin bersifat sepihak, perjanjian berdasarkan

\footnotetext{
${ }^{1}$ Pada tahun 1967 Kontrak Karya I yang dilakukan antara Pemerintah Indonesia dengan PT Freeport Indonesia dalam kurun waktu 30 tahun. Setelah penandatanganan kontrak, PT Freeport Indonesia memulai proses produksi pada tahun 1973 dengan menggunakan teknik pertambangan terbuka (open pit mining). Kemudian di tahun 1981, PT Freeport Indonesia melakukan proyek perluasan kegiatan tambang di daerah tersebut. Hal ini seiring dengan ditemukannya lokasi dengan potensi cadangan mineral baru. Selanjutnya pada tahun 1986, Pemerintah Indonesia mendapatkan divestasi sebesar 8,5 \% dari PT Freeport Indonesia. Sejalan
}

kesepakatan dua pihak; penyelesain sengketa: (5) izin ke PTUN, perjanjian ke arbitrase/alternatif penyelesaian lain di luar pengadilan; (6) kepastian hukum: izin lebih terjamin, perjanjian tergantung kesepakatan dua pihak; (7) hak dan kewajiban: izin hak dan kewajiban pemerintah lebih besar, perjanjian tergantung dua pihak; (8) sumber hukum: izin sumbernya peraturan perundangundangan, perjanjian sumbernya peraturan perjanjian itu sendiri.

Namun, keberadaan KK hingga saat ini menimbulkan beberapa persoalan. Persoalan yang menjadi pertimbangan renegosiasi KK menjadi IUPK yaitu ketidakseimbangan pembagian hasil (revenue sharing) dan ketidakseimbangan posisi tawar (bargaining position) Pemerintah Indonesia dengan perusahaan (Sekretariat Kabinet, 2015).

Besaran royalti yang dibayarkan PTFI terhadap Pemerintah Indonesia hanya berada pada angka $1 \%$. Fakta lapangan yang didapat, bahwa sampai saat ini PTFI belum menyepakati substansi penyesuaian isi IUPK secara utuh terhadap KK. Merujuk pada Peraturan Pemerintah No.9 Tahun 2012 tentang Jenis dan Tarif Penerimaan Negara Bukan Pajak, royalti PTFI mengalami apresiasi menjadi 3,75\% untuk komoditi emas, perak dan tembaga walaupun di sisi PTFI kewajiban tersebut baru dibayarkan pada tahun 2014.

Situasi keseimbangan posisi tawar di antara negara dan PTFI memiliki klausul kesepakatan yang disebut sebagai stabilization clause. Pada dasarnya, kesepakatan tersebut memberartkan

dengan kebijakan Pemerintah Indonesia dalam investasi sejak tahun 1968. Kemudian, Kontrak Karya II mulai dilaksanakan pada tahun 1991 selama 30 tahun ditambah 2 kali 10 tahun dan berahir sampai tahun 2041, karena ditemukan cadangan mineral baru yang sangat besar di daerah Grasberg pada ketinggian $4000 \mathrm{~m}$ dari permukaan laut. Produksi yang semulanya 5000 ton bijih per hari pada awal Kontrak Karya, telah meningkat menjadi 52.000 ton per hari tahun 1991 dan sekarang menjadi sekitar 240.000-250.000 ton per hari. 
posisi Indonesia di dalam penyelarasan posisi tawar. Klausul stabilisasi tersebut mengharuskan negara untuk melakukan renegosiasi sebagai bentuk kesepakatan pertambangan Kontrak Karya (concession agreement) yang tidak bisa diubah begitu saja tanpa kesepakatan pihak di dalam perjanjian sebelumnya (Syaifuddin, 2011). Selain itu, dampak ketergantungan negara terhadap implementasi penanaman modal asing menjadi indikator ketidakseimbangan posisi tawar.

Merujuk pada ketentuan Pasal 112 UU No 4 Tahun 2009, yang diatur di dalam PP No 20 Tahun 2010 tentang Pelaksanaan Kegiatan Usaha Pertambangan Mineral dan Batubara, jumlah saham yang wajib didivestasikan kepada konsesi perusahaan milik Indonesia paling sedikit adalah 20\% (dua puluh Persen). Selang dua tahun berikutnya, pemerintah mengubah PP 23 Tahun 2010 dengan PP 24 tahun 2012 tentang Perubahan atas Peraturan Pemerintah No 23 Tahun 2010 tentang Pelaksanaan Kegiatan Usaha Pertambangan Mineral dan Batubara.

Salah satu perubahan penting yang terdapat dalam PP No 24 Tahun 2012 ini adalah mengenai besar saham yang wajib didivestasikan menjadi paling sedikit $51 \%$ (lima puluh satu persen). Namun, hingga saat ini Pemerintah Indonesia hanya memperoleh 9,36\% (PT Indocooper Investama) kepemilikan saham di PTFI. Dengan klausul saham 51\% seharga US\$ 3,85 miliar, Indonesia masih belum mampu menggelontorkan dana untuk mengakuisisi $51 \%$ kepemilikan saham di PTFI (ESDM, 2018).

Hingga pada tahun 2018 melalui PT Indonesia Asahan Aluminium (INALUM), PTFI dan Rio Tinto melakukan HoA (Head of Agreement) tentang pokok-pokok perjanjian divestasi saham PTFI. Apabila dikaji secara substansial pada mandat hukum pertambangan, kedudukan Pemerintah Indonesia dan PTFI di dalam IUPK berbeda dengan Kontrak Karya. Mandat IUPK berdasarkan pada UU No 4 Tahun 2009 memposisikan Indonesia sebagai regulator yang kedudukannya absolut dan lebih unggul dari perusahaan.

Selain itu, kewajiban melakukan pengolahan dan pemurnian hasil penambangan di dalam negeri tidak hanya berlaku bagi Pemegang IUP dan IUPK Operasi Produksi tetapi juga berlaku bagi pemegang kontrak karya. Namun terdapat perbedaan waktu dalam melaksanakan kewajiban tersebut. Bagi pemegang kontrak karya kewajiban tersebut harus dilaksanakan selambat-lambatnya 5 (lima) tahun sejak UU Minerba diundangkan. Namun bagi pemegang IUP dan IUPK Operasi Produksi berlaku mengikat seketika sejak diundangkannya UU Minerba. Hal tersebut didasarkan pada upaya peningkatan nilai tambah dalam operasional pengolahan dan pemurnian produksi di dalam negeri sesuai dengan Pasal 103 (1) UU No 4 Tahun 2009.

\section{Skenario Daya Tawar Pemerintah Indonesia terhadap PT Freeport Indonesia}

Terjadinya perubahan karakteristik negara yang lebih dominan melalui penerapan UU No 4 Tahun 2009 yang sebelumnya bersifat kontrak dan 'ramah' terhadap pemodal asing, saat ini mencapai transisi di mana negara berupaya menjadikan dirinya sebagai regulator. Sifat komplementer negara terhadap PTFI disesuaikan pada transisi dan sif at regulasi yang didasarkan pada UU No 1 Tahun 1967 tentang Penanaman Modal Asing dan UU No 11 Tahun 1967 tentang Pertambangan Mineral dan Batubara yang secara simultan berubah menjadi UU No 4 Tahun 2009. 
Gambar 1. Skenario Internalisasi Modal

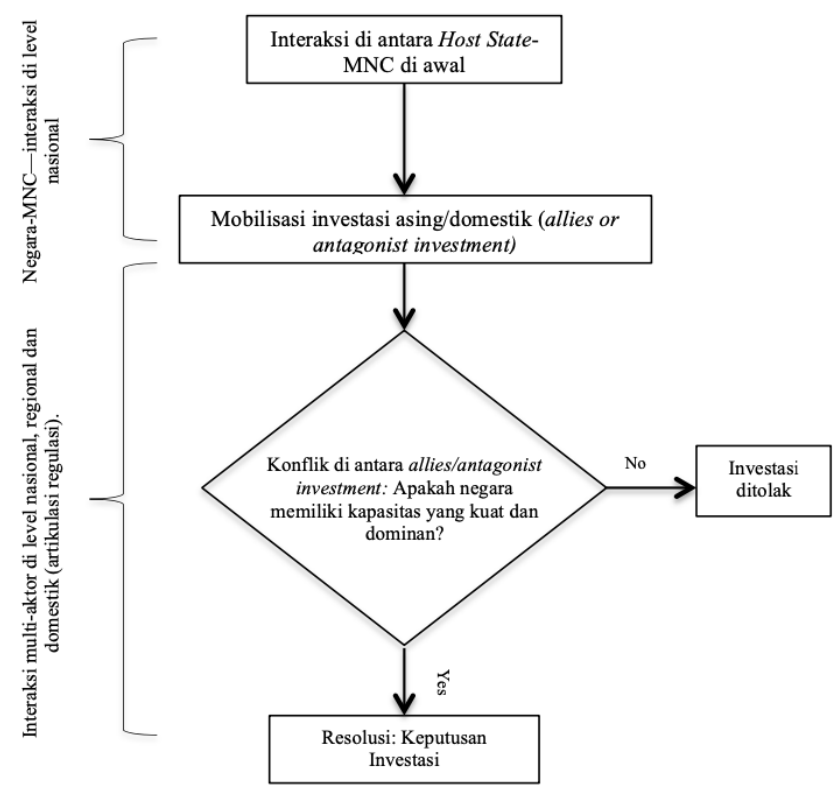

Sumber: diolah, 2020.

Apabila merujuk pada konsep internalisasi dimana keuntungan suatu MNC ditentukan oleh karakteristik kepemilikan, lokasi dan internalisasi; PTFI sebagai sebuah pintu masuk penanaman modal asing hampir memenuhi semua karakteristik kepemilikan dalam mengindikasikan komponen-komponen relatif atas keunggulan posisi tawar PTFI daripada posisi Pemerintah Indonesia. Representasi atas FDI (Foreign Direct Investmen) dan arus kapital sebagai konfigurasi kekuatan pasar global yang membayang-bayangi PTFI. Peralihan Kontrak Karya menjadi IUPK secara substantif telah merubah pemaknaan negara terhadap sifat komplementer menjadi protektif.

Dalam konsep pendekatan state-centric, model pendekatan tersebut menitikberatkan negara sebagai unit koheren dalam upaya pemusatan negara ke dalam kebijakan industri. Oatley berpendapat bahwa pendekatan statecentric mengasumsikan negara dan birokrasi pemerintah dapat mengoperasionalkan secara independen tekanan dari kelompok kepentingan, termasuk kepentingan industri di dalam sektor privat (Leiteritz, 2004: 109).

Dalam situasi yang otonom, Pemerintah Indonesia merealisasikan upaya intervensi terhadap industri pertambangan domestik melalui penerapan UU No 4 Tahun 2009 dengan landasan penambahan nilai tambah dan meningkatkan kualitas kompetitif pemerintah dalam perdagangan global. Selain situasi protektif yang dihasilkan pemangku kebijakan melalui regulasi Undang-Undang pertambangan, upaya mendorong 'infant industry' dalam hal tersebut yaitu PT Indonesia Asahan Aluminium sebagai Badan Usaha Milik Negara (BUMN) secara teknis mengakumulasikan format late industrialization dengan risiko kehilangan keuntungan jangka pendek.

Secara politis, set kebijakan ini yang disebutkan sebagai traditional protectionism. Pemerintah Indonesia berperan sebagai promotor untuk PT Indonesia Asahan Inalum yang dipengaruhi oleh komposisi keuntungan kapital domestik yang dominan oleh host state. Karakteristik Indonesia apabila merujuk pada konsep state centric, Indonesia merupakan 'negara kuat' dan secara eksplisit mengedepankan kepentingan negara di balik agenda nasionalisasinya. Dalam memformulasikan kebijakan industri pertambangan tersebut, Pemerintah Indonesia menggulingkan fungsi kontrol pasar pertambangan dengan proses pengambilalihan perusahaan.

Merujuk pada proses penyeimbangan daya tawar Bennet dan Sharpe, pada kasus Pemerintah Indonesia dan PT. Freeport Indonesia sudah hampir memenuhi indikator yang diindikasikan. Baik pengambilan alih perusahaan melalui divestasi saham, perubahan regulasi yang merugikan negara secara fundamental serta renegosiasi Kontrak Karya menjadi IUPK. Apabila ditinjau dari dimensi politiknya, posisi tawar Pemerintah Indonesia sebagai Host-State hanya bertumpu pada konteks politiknya saja. Walaupun kenyataannya, hubungan bisnis di antara keduanya bersifat relatif. Alih-alih menitikberatkan relasi tawar menawar yang bersifat dominan, Pemerintah Indonesia membutuhkan modal besar dalam industri padat karya seperti tembaga.

Restriksi aktivitas ekspor konsentrat tembaga yang dilakukan oleh Pemerintah 
Indonesia mendorong pemenuhan konsumsi produk tembaga di pasar domestik. Skema positif keberlanjutan melalui perusahaan domestik, melalui UU No 4 Tahun 2009 berusaha mereduksi peran PTFI di dalam pasar. Sehingga, produktivitas perusahaan domestik dapat mencapai kondisi pasar yang proporsional (Gilpin \& Gilpin, 2011: 123).

Dalam situasi yang komplementer, telaah situasi terhadap sikap Pemerintah Indonesia yang mensituasikan kebijakan fiskal dan bea keluar tidak relevan dengan situasi hilirisasi produk tembaga yang masih liberal. Penolakan yang dilakukan oleh PTFI sebelumnya bukan tanpa alasan, melainkan mempertimbangkan aktivitas regulatif yang dilakukan negara tidak kooperatif. PTFI menganggap tindakan tersebut sebagai upaya negara untuk menekan kerugian secara sepihak.

Selain itu, restriksi terhadap hilirisasi dengan pelarangan ekspor tambang mentah menghambat pemrosesan produk di hilir. Sirkulasi kebijakan serta keterkaitan institusi semakin membuat proses hilirisasi produk tambang menjadi rentan. Walaupun kedudukan bargain Pemerintah Indonesia tidak signifikan terhadap PTFI, namun atribut pemerintahan dalam menentukan kapasitasnya untuk menggiring arus kepentingan kepada dominasi industri, secara simultan telah mencapai variabel keseimbangan posisi tawar (equilibria). Oleh karena itu, asumsi bahwa regulasi yang protektif menjadi mungkin apabila negara sebagai entitas berdaulat dan PTFI sebagai aktor utuh dalam relasi daya tawar menemui kepentingan yang berbeda sehingga harus mencapai titik resolusi keseimbangan yang baru. Maka, renegosiasi yang melibatkan variabel state-centric untuk menentukan kapasitas negara sebagai 'negara kuat' mampu mengakumulasikan kedaulatannya dalam perangkat kebijakan yang solid dan konsisten.

Paradigma neomerkantilisme dalam studi kasus Pemerintah Indonesia dan PTFI menyimpulkan peran negara dalam mengaugmentasi kekuatan negara ke dalam kekuatan pasar, terutama terhadap PTFI sebagai aktor pasar tembaga. Preferensi tersebut telah menciptakan relasi yang konfrontatif akibat Pemerintah Indonesia mengambil sikap yang merugikan secara bisnis di dalam rezim pasar pertambangan. Sehingga, konsekuensi jangka pendek pun sulit dihindarkan. Di mana negara menanggung biaya operasional yang tinggi dengan risiko investasi, sekaligus melawan norma pasar neoliberal yang pada saat ini mengalami penurunan signifikan di dalam sektor komoditas.

Akan tetapi, situasi tersebut dibenarkan apabila spektrum kedaulatan pada paradigma neomerkantilisme didekonstruksi menjadi pilihan-pilihan strategis Pemerintah Indonesia dalam mereduksi interdependensi serta regulasi yang terlalu berorientasi pada pasar. Kombinasi kontrol produksi serta keistimewaan negara dalam mengakses sumber dayanya secara esensial (pada relasi Pemerintah Indonesia dan PTFI), menempatkan posisi negara menjadi dominan dan melemahkan PTFI dalam mekanisme liberalisasi pasar minerba yang tidak sempurna. Sehingga, disimpulkan bahwa karakteristik regulasi melalui renegosiasi KK menjadi IUPK telah memposisikan negarapada daya tawar yang dominan dan PTFI tentu tidak diuntungkan dalam skenario ini.

\section{Artikulasi Posisi Tawar Pemerintah Indonesia dan PT Freeport Indonesia}

Upaya tarik-menarik daya tawar dalam renegosiasi IUPK secara runut dimaknai dengan mendasar atas perubahan rezim kontrak menjadi perizinan. Namun dalam situasi kontrak PTFI yang masih berlaku hingga tahun 2021, Pemerintah Indonesia masih mengindahkan ketentuan aturan kontrak di dalam UU No. 4 tahun 2009 dalam Pasal 169 a UU Minerba bahwa dalam muatan UU tersebut, Pemerintah Indoneia masih mengakui isi perjanjian dari kontrak karya.

Pasal 169 a UU Minerba berbunyi, sebagai berikut: "Kontrak Karya dan perjanjian karya pengusahaan pertambangan batubara yang 
telah ada sebelum berlakunya Undang-Undang ini tetap diberlakukan sampai jangka waktu berakhirnya kontrak/perjanjian”.

Muatan Pasal 169 a menyebabkan situasi ketidakpastian kedudukan pemerintah dalam urusan teknis seperti halnya dalam konteks pengelolaan pertambangan. Walaupun secara normatif kedudukan Pemerintah Indonesia lebih tinggi, namun status kedudukan tinggi tersebut berada pada teritorial regulator alihalih sebagai pelaku bisnis. Dengan demikian, pengakuan Pemerintah terhadap eksistensi Kontrak Karya merupakan celah bargaining PTFI untuk melakukan penundaan perubahan KK menjadi IUPK.

Saham PTFI secara mayoritas dimiliki oleh Amerika Serikat dengan total akumulasi sekitar 90,64 Persen (Sembilan puluh koma enam puluh empat persen). Sebaliknya, Pemerintah Indonesia yang direpresentasikan oleh Kementerian Pertambangan dan Energi hanya memiliki akumulasi saham sebesar 9,36 Persen (Sembilan komatiga puluh enam persen). Dengan perbandingan kepemilikan tersebut, 9,36 persen tentu saja bukanlah suatu angka kepemilikan akhir yang optimal. Dengan kata lain, perolehan dividen dan pendapatan pajak dinilai tidak koheren dengan konsekuensi sumber daya pertambangan yang diserap. Terlebih lagi, peran pemerintah Indonesia tidak signifikan dalam proses manajemen perseroan baik dari sisi perencanaan, proses pengorganisasian secara institusional, kepemimpinan pasar, fungsi pengendalian untuk mempromosikan kepentingan nasional di dalam PTFI.

Ketentuan divestasi yang merupakan bagian fundamental dari UU. No 4 Tahun 2009 dan pelaksananya pada PP No 1 tahun 2017 mensubstitusikan kembali detail divestasi sahamnya yang tertuang pada KK. Sedangkan pada pasal 97 ayat (1), dinyatakan bahwa Pemegang IUP dan IUPK dalam konteks penanaman modal asing, ditentukan bahwa setelah kurun waktu 5 (lima) tahun sejak dimulai proses produksi, perseroan wajib melakukan divestasi sahamnya secara berangsur-angsur hingga mencapai paling sedikit $51 \%$ total kepemilikan. Kenyataannya, Pemerintah Indonesia sebagai host country tidak memiliki hak istimewa dan hanya berperan sebagai minoritas apabila ditinjau berdasarkan cost-benefit ratio. Oleh karena itu, ada beberapa poin pengkondisi posisi tawar PTFI yang mengalami pereduksian, antara lain sebagai berikut:

- Larangan ekspor komoditas mentah yang tercantum pada pasal 102 SDAN dan 103 UU No 4 Tahun 2009 dan Permen ESDM No. 7 tahun 2012 di mana PTFI mendapatkan izin mengekspor konsentrat tembaga apabila mengubah KK menjadi IUPK.

- Divestasi saham 51\% yang secara substantif tertuang pada KK II yang secara berangsur-angsur PTFI harus melepas $51 \%$ sahamnya. Kemudian, berdasarkan PP No. 1 Tahun 2017 dimana penyesuaian KK dan IUPK dilakukan secara konsensual untuk melakukan amandemen yang menghasilkan peningkatan royalty tembaga dari tiga persen menjadi empat persen.

- PTFI dianggap melakukan pengingkaran terkait proses divestasi $51 \%$ saham di mana dalam kurun waktu 20 tahun sejak Kontrak Karya ditandatangani, dalam rentang waktu yaitu paling lambat pada tahun 2011, dijelaskan bahwa PTFI harus melepas saham sebesar $45 \%$ jika $20 \%$ saham PTFI sudah dimiliki pemerintah secara bertahap sebagaimana kehendak UU No 4 tahun 2009.

\section{KESIMPULAN}

Upaya intervensi negara melalui pemberlakuan UU No 4 Tahun 2009, secara otentik merubah komponen kebijakan perdagangan dan industri pertambangan mineral dan batubara. Terjadi keunikan di antara dinamika relasi Pemerintah Indonesia dan PTFI (MNCs) pada proses renegosiasi sehingga mempengaruhi dinamika posisi tawar di antara keduanya.

Sebelumnya, Pemerintah Indonesia dianggap tidak rasional dalam mencanangkan 
restriksi

perdagangan

tanpa

mempertimbangkan arus kapital dan kelesuan finansial pada masa transisi penurunan harga komoditas primer di pasar global. Konsekuensinya, PTFI dalam ruang lingkup aktor yang terdampak akibat perubahan regulasi tersebut menyebabkan terjadinya pertikaian dan konfrontasi. Dalam skenario konfrontatif, Pemerintah Indonesia menjadi aktor dominan sebagai entitas yang berdaulat.

Temuan yang menarik berada pada bagaimana peran intervensi Pemerintah Indonesia bukan semata-mata tindakan reaktif akibat dari dorongan nasionalisasi sumber daya esensial. Justru, motif utamanya berada pada agenda 'penataan ulang' industri pertambangan. Dalam konteks yang lebih pragmatis, profil aksi serta bagaimana dinamika relasi keduanya justru menghasilkan tesis bahwa negara sebagai pelaku pasar memiliki kedudukan yang sama bahkan lebih dominan dibandingkan dengan PT Freeport Indonesia.

\section{DAFTAR PUSTAKA}

Bennett, D., \& Sharpe, K. E. (1979). Transnational corporations and the political economy of export promotion: The case of the Mexican automobile industry. International Organization, Columbia: University of South Carolina Press.

Bogdan, R., \& Biklen, S. K. (2003). Bogdan, R. C \& Biklen, S. K. (2003). Qualitative Research for Education: An introduction to Theories and Methods (4th ed.). New York: Pearson Education group. (pp. 110-120). Qualitative Research for Education: An introduction to Theories and Methods. Allyn and Bacon, Inc.: Boston London.

BUSER, S. A., CHEN, A. H., \& KANE, E. J. (1981). Federal Deposit Insurance, Regulatory Policy, and Optimal Bank Capital. The Journal of Finance.

Evenett, S. J. (2014). The Global Trade Disorder. The 16th GTA Report. CEPR Press.

Gilpin, R. (2016). The political economy of international relations. In The Political Economy of International Relations. Princeton, NJ: Princeton University Press. Gilpin, R., \& Gilpin, J. M. (2011). Global political economy: Understanding the international economic order. In Global Political Economy: Understanding the International Economic Order. Princeton, NJ: Princeton University Press.

Grosse, R. (2005). The bargaining view of government-business relations. In International Business and Government Relations in the 21st Century. Cambridge: Cambridge University Press.

Hettne, B. (1993). Neo-Mercantilism: The Pursuit of Regionness. Cooperation and Conflict, 28(3), 211-232.

Indonesia, Peraturan Pemerintah Nomor 24 Tahun 2012 Tentang Pelaksanaan Kegiatan Usaha Pertambangan Mineral dan Batubara, Lembaran Negara Republik Indonesia(LNRI) Tahun 2012 Nomor 45 Tahun 2012, Tambahan Lembaran Negara (TLN) No. 5597. Pasal 112.

Kementerian Energi dan SumberDaya Mineral, Keputusan Menteri ESDM tentang Pedoman Pemerosesan Permohonan KK dan PKP2B dalam rangka PMA. Keputusan MenteriESDMNo. 1614 Tahun2004. Pasal 1 angka 1 .

Leiteritz, R. J. (2004). Thomas Oatley: International political economy. Interests and institutions in the global economy. Politische Vierteljahresschrift: Blackwell Publishing.

Marks, S. (2020). Asia-Pacific Trade and Investment Report 2019: Navigating NonTariff Measures towards Sustainable Development . Bulletin of Indonesian Economic Studies.

Mastanduno, M. (1991). Do Relative Gains Matter? America's Response to Japanese Industrial Policy. International Security 16(1), 73-113.

Matthews, F. (2012). Governance and State Capacity. In The Oxford Handbook of Governance, Oxford University Press.

Neuman, W. L. (2014). What are the Major Types of Social Research? Social Research Methods: Qualitative and Quantitative Approaches. Boston: Allyn and Bacon

Pierre, J., Peters, B. G., \& Bradford, N. (2001). Governance, politics and the state. Environment and Planning C: Government and Policy. Macmillan: Red Globe Press.

Ramamurti, R. (2012). Competing with emerging market multinationals. Business 
Horizons. Cambridge University Press: Cambridge, U.K.

Sektretariat Kabinet. (2015, Juli 14). Catatan

Atas Renegosiasi Kontrak. Dipetik Desember 14, 2020, dari https://setkab.go.id/catatan-atas-

renegosiasi-kontrak/

Stopford, J., Strange, S., \& Henley, J. S. (1991). Rival states, rival firms: competition for world market shares. Rival states, rival firms: competition for world market shares. Cambridge University Press.

Sulistyorini, I., \& Zulaekhah, S. (2018). Economic Analysis of Law Pada Perubahan Kebijakan Kontrak Karya Menjadi Ijin Usaha Pertambangan Khusus (IUPK): Studi Kasus Pt. Freeport Indonesia. Pena Justisia: Media Komunikasi dan Kajian Hukum.

Syaifuddin, M. (2011). PERSPEKTIF GLOBAL PENYELESAIAN SENGKETA INVESTASI DI INDONESIA. Journal de Jure: Maulana Malik Ibrahim State Islamic University.

UU Minerba No.4 Tahun 2009 tentang Pertambangan Mineral dan Batubara.

Warnecke, S. J. (1979). Defending the National Interest: Raw Materials Investments and US Foreign Policy. International Affairs. Princeton: Princeton University Press.

Zohrabi, M. (2013). Mixed method research: Instruments, validity, reliability and reporting findings. Theory and Practice in Language Studies. Finland: Academy Publisher.

\section{BIOGRAFI}

Angga Danu Fadil Irawan, Sarjana Ilmu Hubungan Internasional Universita s Pasundan yang saat ini bekerja sebagai konsultan dalam isu-isu pembangunan sosial di salah satu NGO di Jakarta. Penulis memiliki ketertarikan dalam isu Ekonomi Politik Global, Post-Struktura lisme dan Feminisme. 